УДК 378.011.3-051:81'243 (091) (477.83/.86)

DOI https://doi.org/10.26661/2522-4360-2021-2-02

\title{
ПІДГОТОВКА ВЧИТЕЛІВ ІНОЗЕМНИХ МОВ ДЛЯ ГІМНАЗІЙ СХІДНОЇ ГАЛИЧИНИ (1867-1914 РОКИ)
}

\author{
Федурко-Попик Ю. С. \\ аспірант кафедри загальної педагогіки та дошкільної освіти \\ Дрогобиџький державний педагогічний університет імені Івана Франка \\ вул. Івана Франка, 24, Дрогобич, Львівська область, Украӥна \\ orcid.org/0000-0002-9995-2129 \\ ufedurko@gmail.com
}

\author{
Ключові слова: \\ Австро-Угорська імперія, \\ Східна Галичина, класична \\ гімназія, іноземні мови, \\ підготовка вчителя іноземних \\ мов, кваліфікаиійний іспит.
}

У статті йдеться про специфіку підготовки вчителів іноземних мов для класичних гімназій Східної Галичини в період їі перебування у складі Австро-Угорськоїімперії. Уній, зокрема, стверджено, що класичнагімназія була основним елементом тогочасної системи середньої освіти, оскільки до початку XX століття тільки іiі завершення уможливлювало доступ до університетських студій. Це, з одного боку, засвідчувало особливу роль класичних гімназій у розвитку інтелектуальних сил українського народу та формуванні його еліти, а із другого - розширювало систему вимог до фахової підготовки гімназійного вчителя, його особистісних якостей і загальної ерудиції.

Автор наголошує на актуальності гімназійної проблематики в контексті Східної Галичини в сучасному історико-педагогічному дискурсі, увиразнює основні аспекти тих досліджень, що послугували підгрунтям для iіi розвідки й уможливили досягнення поставленої мети - простежити джерела, чинники й особливості професійної підготовки вчителів іноземних мов для гімназій Східної Галичини в автономічну добу. У статті продемонстровано багатоступеневість процесу формування особистості гімназійного вчителя загалом та вчителя іноземних мов зокрема, названо його ступені, виокремлено завдання та сутнісні ознаки кожного 3 них. Першим ступенем для вчителів іноземних мов визнано навчання на філософському факультеті університету. До його особливостей зараховано опанування профільних і допоміжних дисциплін, предметів психологопедагогічного циклу, участь у практикумах і семінарах. Другий ступінь складання складного і трудомісткого кваліфікаційного іспиту перед комісією, склад і чинність якої регламентувало віденське Міністерство віросповідань і освіти. Він містив етап домашнього завдання (підготовка письмової роботи на певну тему 3 основної й допоміжної дисциплін iз подальшим їх оцінюванням), етапи письмового й усного екзамену перед комісією. Сутність наступного ступеня становили самоосвіта й саморозвиток, спрямовані на збагачення власного педагогічного досвіду й піднесення свого інтелектуального рівня. 


\title{
TRAINING OF FOREIGN LANGUAGE TEACHERS FOR GYMNASIUMS OF EASTERN GALICIA (1867-1914)
}

\author{
Fedurko-Popyk Y. S. \\ Postgraduate Student at the Department of General Pedagogy and Preschool Education \\ Drohobych State Pedagogical University named after Ivan Franko \\ Ivana Franka str., 24, Drohobych, Lviv region, Ukraine \\ orcid.org/0000-0002-9995-2129 \\ ufedurko@gmail.com
}

\begin{abstract}
Key words: Austro-Hungarian Empire, Eastern Galicia, classical gymnasium, foreign languages, training of foreign language teachers, qualifying exam.
\end{abstract}

\begin{abstract}
The article deals with the specifics of training foreign language teachers for the classical gymnasiums of Eastern Galicia during its stay in the AustroHungarian Empire. In it, in particular, it is stated that the classical gymnasium was the main component of the then system of secondary education, because by the beginning of the twentieth century. only its completion provided access to university studies. This, on the one hand, testified to the special role of classical gymnasiums in the development of intellectual forces of the Ukrainian people and the formation of its elite, and on the other - expanded the system of requirements for professional training of high school teachers, his personal qualities and general erudition.

The author emphasizes the relevance of gymnasium issues in the context of Eastern Galicia in modern historical and pedagogical discourse, highlights the main aspects of research that served as a basis for its exploration and made it possible to achieve the goal - to trace the sources, factors and features of foreign language teachers' training. in the autonomous era. The article demonstrates the multi-stage process of forming the personality of a high school teacher in general and a foreign language teacher in particular, names its degrees, highlights the tasks and essential features of each of them. The first degree for foreign language teachers is recognized at the Faculty of Philosophy of the University. Its features include mastering specialized and auxiliary disciplines, subjects of the psychological and pedagogical cycle, participation in workshops and seminars. The second stage is passing a complex and time-consuming qualifying examination before a commission, the composition and validity of which were regulated by the Vienna Ministry of Religion and Education. It contained a stage of homework (preparation of written work on a certain topic in the main and auxiliary disciplines with their subsequent assessment), stages of written and oral examination before the commission. The essence of the next degree was self-education and self-development, aimed at enriching their own pedagogical experience and raising their intellectual level.
\end{abstract}

Постановка проблеми. Особлива увага суспільства до освіти і школи в сучасну інформаційну добу пояснює і його високі вимоги до вчителів, бо насамперед від їхньої кваліфікації, компетентностей, настанов, особистісних характеристик значною мірою залежить успішність навчання й виховання. «Немає, - наголошує відомий польський педагог В. Оконь, - жодної такої освітньої системи, яка б легковажила роллю вчителя в навчальному процесі. Попри наявні поміж цими системами суттєві відмінності, їхні представники єдині в думці, що добра освіта й добре виховання може бути справою лиш доброго вчителя-вихователя» [8, с. 357]. У підготовці такого вчителя для сучасної української школи загалом та вчителя іноземних мов зокрема важливим $є$ врахування досвіду попередніх поколінь, у скарбівню якого немало цінного внесли освіта і школа Східної Галичини 1867-1914 pp.

Досвід шкільництва Галичини в період іï вимушеного перебування під австрійським пануванням в останні 30 років залишається предметом ретельного опрацювання дослідників (праці С. Гелей, І. Курляк, Н. Мисак, Г. Ріккарді, 3. Саф'янюк, В. Стинської, Б. Ступарика, Р. Яковишина, Б. Янишина й інших). Виявляємо деяке зацікавлення і проблемами підготовки вчительських кадрів - див., наприклад, дисертаційну працю А. Вараниці про вчителів народних шкіл [1], статтю 3. Нагачевської про джерела, специфіку, чинники формування системи професійної 
підготовки вчителів на українських етнічних територіях Галичини до 1939 р. [7], І. Гаврищака й О. Проців про кадровий склад гімназій Галичини у другій половині XIX ст. і особливості його формування [2]. Не залишаються поза увагою вчених і питання розбудови у Східній Галичині гімназійної освіти, як і підготовки фахівців для неї; тут попереду польські дослідники $[15 ; 16]$. Український історик О. Коцюмбас проаналізувала вчительський склад Львівської академічної гімназії від другої половини XIX ст. до початку XX ст. і дійшла висновку про незмінно високий рівень його фаховості та про національну спрямованість діяльності, оскільки всі вчителі за «своїм науково-методичним рівнем відповідали тогочасним вимогам європейських стандартів», а плекання національної еліти вважали найважливішим зі своїх обов'язків [4, с. 59-60]. Цей період, особливо перелом XIX-XX ст., позначений розвитком нових концепцій навчання і виховання, найважливішими характеристиками яких учені вважають увагу до учня, урахування його можливостей і здібностей, особистісних якостей, виховання самостійності й активності, розвиток навичок самонавчання й самовиховання, а також досягнення індивідуального успіху [18, с. 88$]$.

Згадані розвідки продовжують у певний спосіб дослідження, підготовлені в аналізований період або ж у часі, що йшов безпосередньо після нього $[12 ; 17]$. Проте праць із розгляду особливостей підготовки вчителів іноземних мов усе ж бракує, попри те, що мовна освіта в тогочасних класичних гімназіях займала понад $60 \%$ навчального часу, а кількість гімназій, хоч і повільно, та все ж зростала [5]. Паралельно збільшувалась і чисельність педагогічних працівників: якщо вчительський збір Львівської академічної гімназії в 1875/1876 н. р. становив 17 осіб [19, с. II], то в 1893/1894 н. p. - уже 28 [8, с. 5].

Мета статті - проаналізувати джерела, чинники та специфіку професійної підготовки вчителів іноземних мов для гімназій Східної Галичини в автономічну добу.

Виклад основного матеріалу дослідження. XIX ст. започаткувало на галицьких землях, що стали після переділів Польщі частиною Габсбурзької монархії, новий тип учителя, головним обов' язком якого стало формування духовно багатої особистості, яка «дбатиме про минуле рідного народу, любитиме свою мову, свою літературу і шануватиме великих людей своєї нації» [20, с. 37].

Суттєво, що підгрунтя для так трактованого педагогічного вишколу в середовищі українців (по-тодішньому - русинів) Галичини на той час уже було сформоване [7, с. 21-22], хоча стан галицького шкільництва на початок австрійського панування оцінюють досить критично.

Польський дослідник Ч. Галек після проведення аналізу вимог австрійської влади до особи- стісних характеристик учителя автономічної доби дійшов таких висновків: він мав бути «<...> релігійним, благочестивим, лояльним, лагідним, невибагливим, послужливим, безкорисним, людяним, ніжним, терплячим, скромним, чемним, статечним, тактовним, стриманим, ввічливим, сумлінним, справедливим, поступливим, вирозумілим, веселим, розумним, практичним, розважливим, хазяйновитим, пильним, старанним, працьовитим, свідомим, кмітливим, пунктуальним, слівним, енергійним, освіченим, обережним, послідовним, музикальним, здоровим» [15, с. 122]. Цей набір якостей був, звісна річ, ідеалом, до якого мав змагати кожен, хто зробив чи прагнув зробити вчительство справою свого життя. Більшість 3 учителів цьому ідеалові відповідала: вони «були дійсними приятелями молодіжі, уміли єднати собі iï прихильність і довірливість, поступали в школі оглядно, тактовно і по найбільшій часті безсторонньо, заохочували оскілько мож до самостійного мислення, до застанови над предметом, до котрого вміли збудити цікавість» [11, с. 11]. Проте траплялися серед учительського загалу й такі одиниці, що не вважали за обов'язкове плекати в собі згадані вище якості - див., для прикладу, оповідання I. Франка «Отець-гуморист».

Тогочасне вчительське середовище не було однорідним: його репрезентували вчителі народних шкіл, однокласних, двокласних, трикласних, чотирикласних, класичних гімназій, учительських семінарій, реальних шкіл і гімназій. Учителі класичних гімназій належали до педагогічної еліти $[16$, с. 6] як з погляду рівня освіченості й активності в науковому та культурному житті краю, так і з огляду на місце гімназії в тодішній системі освіти. Ї̈̈ роль у формуванні молодих характерів I. Франко, випускник Дрогобицької гімназії, вустами головного героя 3 оповідання «Борис Граб» окреслив так: «Гімназія вчить вас володіти духовими органами, виробляє пам'ять, порядне думання, систематичність, а нарешті критичність. Отсе мета гімназії. Гімназія - се та ж гімнастика, лише на широкій, духовій основі» [10, с. 179].

Тож абсолютно переконливим виглядає твердження автора опублікованої 1891 р. статті про діяльність семінарії 3 підготовки вчительських кадрів, заснованої 1780 р., згідно з розпорядженням Едукаційної комісії, першого в Свропі Міністерства народної освіти [3, с. 79], при головній школі Кракова: «Реформа сучасної системи навчання кандидатів на вчителів середніх шкіл - одна 3 найважливіших проблем у системі галицького шкільництва, нею переймаються не тільки педагоги, але й ті прошарки нашої суспільності, яким не байдуже майбутнє нашої молоді» [17]. Адже здобуття грунтовної загальної освіти як провідної мети діяльності гімназій могли забезпечити лиш ті, хто самі їі мали. 
Відповідно вимоги щодо підготовки вчительських кадрів для середніх шкіл загалом і гімназій зокрема щораз зростали. Чи не найважливішою серед них треба визнати ту, що визначила: від 1859 р. кандидати на посаду гімназійного вчителя мають відбувати 4-річні університетські студії: 5 семестрів на філософському факультеті, 3 - на філософському чи будь-якому іншому, пов'язаному 3 майбутньою спеціалізацією. Хоч молодь Східної Галичини могла навчатися і в університетах Берліна, Варшави, Відня, Праги тощо, проте обирала в основному Львівський чи Краківський університети. Були деякі відмінності в підготовці фахівців із тих чи тих спеціальностей. Скажімо, майбутні вчителі фізики, математики, геометрії перші 2 роки, хімії - 3 роки мали навчатися в політехніці, а студенти-філологи, для яких філософський факультет був основним і здебільшого єдиним, могли відбувати піврічне стажування у країні виучуваної мови (замість 2-х семестрів практики), щоб набути вправності у володінні мовою. До речі, стипендію на навчання в закордонних університетах Крайова шкільна рада надавала й після завершення повного університетського курсу. Так, у 1905/1906 н. р. вона виділила 60 стипендій для навчання вчителів німецької мови в університетах Відня, Граца, Інсбрука, 13 - на студії в Парижі для майбутніх учителів французької мови [21, с. 19].

Високі вимоги висувалися не лише до фахової підготовки, але й до загального розвитку майбутніх учителів: на думку університетських влад, студенти мали набувати й тих знань, які можуть їм пригодитися на кваліфікаційному / вчительському іспиті чи у професійній діяльності. Крім фахових дисциплін, кожен із них мав вивчати філософію (зокрема, антропологію і психологію) та педагогіку разом з історією педагогіки [14, с. 302]. Суттєво, що і тодішня шкільна влада, і вчителі-практики усвідомлювали важливість не лише знань із психології та педагогіки, але й практичних умінь i навичок для успішної професійної діяльності, акцентували на необхідності більшого пристосування університетських викладів до потреб середньої школи [13, с. 165]. I це попри те, що програми навчання передбачали участь у семінарах і практикумах, вивчення курсу методики навчання того предмета, який обрано майбутньою спеціалізацією, також шкільної гігієни, фізичного виховання й мови навчання [16, с. 54], якою в тогочасних гімназіях Східної Галичини могла бути одна із двох крайових мов - польська (в основному) чи українська: із чинних тут у 1913/1914 н. р. 28 гімназій тільки 6 були українськими, 2 - у Бродах та II гімназія Львова - німецькими [16, с. 24-28]. Обов' язковим було опанування суміжних дисциплін. Для майбутніх учителів класичних мов (грецька й латинська) такою була археологія: 2 семестри теоретичного навчання й 1 семестр практики [16, с. 55]. Важило також, який предмет майбутньої діяльності студенти вибирали основним (вимоги були вищими), а який - допоміжним.

Однак завершення університетського курсу ще не давало повноцінного права на працю в гімназії, університет лиш відкривав дорогу до його здобуття. Ця дорога було непростою, а нерідко й тривалою, бо необхідно було скласти кваліфікаційний іспит перед спеціальною комісією початково iз 12, а згодом - із 20 осіб. Доктор філософії, ц.-к. професор Костянтин Лучаківський у посмертній згадці про свого колегу й давнього друга, професора Львівської академічної гімназії Дам'яна Гладиловича наголошує на такому: «Тодїшні професори унїверзитетскі допускали хочби і найлїпших своїх студентів до іспиту доперва по 8-10 літах» [6, с. 45]. Тож нерідко випускники подавалися в ті краї (скажімо, до Віденського університету, як згаданий проф. Д. Гладилович), де ймовірність скласти іспит швидше була вищою. Комісія при Львівському університеті працювала з 1850 p. i була підзвітною, як і всі інші в державі, Міністерству віросповідань і освіти.

Основу таких комісій становили професори університетів, хоч до їхнього складу могли бути залучені за поданням обраного із членів комісії директора також відомі у краї вчителі-практики. Кожен претендент на посаду вчителя (у нашому випадку - учителя іноземних мов), яким міг бути і студент останнього курсу університету, хоч найчастіше - учитель-суплент, до початку екзаменаційних випробувань мав подати в комісію відповідні документи, а саме: а) документ про завершену середню освіту; б) легітимаційну книжку студента університету; в) свідоцтво про працю в гімназії; г) документи, які підтверджують участь у практикумах і семінарах, - для майбутніх учителів живих (новочасних) мов; г) характеристику, якщо із часу завершення університетських студій минуло більше ніж 1 рік і випускник не був задіяний у сфері освіти; д) детальну автобіографію [2, с. $55 ; 16$, с. 56].

Відповідно до тогочасної практики працю в гімназії розпочинали 3 посади заступника вчителя (суплента по-тодішньому). Право на ऑii заміщення давала відповідна ухвала Крайової шкільної ради $[19,1876$, с. III]). У суплента було традиційне для вчителя коло обов'язків, поряд із якими - ще й підготовка до кваліфікаційного іспиту [2, с. 54]. Проте заробітна плата була суттєво нижчою, що стримувало більш здібних і підприємливих людей від професії вчителя [13, с. 145-146]. Із 70-80-х рр., коли суспільство стало щораз активніше виявляти зацікавлення гімназійною освітою, рішенням Крайової шкільної ради суплентам надавано оплачувану 
піврічнувідпусткудляпідготовкидоіспитуабознижуванотижневенавантаження. Зокрема, у1905/1906н.p. оплачувану відпустку отримав 31 кандидат на вчителя, а менше навантаження - 36 [21, с. 20].

За пропозицією Леона Кульчинського із Кракова, озвученою на Першому педагогічному конгресі [13, с. 164], при деяких гімназіях - св. Анни та III Кракова, Академічній, V та VI Львова - 3 1895 р. стали організовувати курси практичної підготовки кандидатів на вчителів із призначенням стипендії в 500 корон і винагороди тим учителям, які керували цією підготовкою [20, с. 18]. Гімназіям, які мали відповідні на це умови, дозволено новопризначених суплентів віддавати під оруду досвідчених учителів, зрозуміло, за відповідну винагороду останнім [20, с. 18].

Кваліфікаційний іспит для вчителів усіх спеціальностей проходив у 3 етапи й вимагав певних фінансових затрат, щонайменше 90 корон - на оплату допуску до кваліфікаційного іспиту загалом та за повідомлення про можливість приступити до II його етапу [16, с. 66]. I етап передбачав виконання домашнього завдання - письмової роботи (з головного й допоміжного предметів) загальнофілософського, педагогічного чи дидактичного характеру, у якій автор мав продемонструвати не лише знання свого предмета, а й загальну ерудицію та вміння працювати з науковою літературою. Термін виконання цих завдань -3 місяці; продовження терміну до пів року потребувало поважного обгрунтування. II етап - завдання при комісії - мав виявити обсяг знань із предмета викладання; він не допускав використання допоміжної літератури; час виконання завдань 3 основного предмета -8 годин, допоміжного 4. III етап - усний екзамен; на ньому перевіряли рівень володіння предметом; для вчителів іноземних мов - це насамперед практичні навички володіння мовою [2, с. $56 ; 16$, с. 159-60].

Як видно з наведеного, кожен із претендентів мав право екзаменуватися з основного й допоміжного предметів. Перший давав право викладати у вищих (V-VIII) класах гімназії, другий - тільки в нижчих (I-IV класах). Усний іспит з основного предмета тривав понад 1 годину, допоміжного - пів години. Для вчителів іноземних мов традиційним було таке поєднання предметів: класична філологія і польська мова, класична філологія та руська мова, польська мова і класична філологія, руська мова i класична філологія, польська і французька мови, польська і німецька мови, німецька мова і класична філологія, філософська пропедевтика і класична філологія [2, с. 56]. Претенденти на викладачів класичних мов виконували домашню письмову роботу латинською або грецькою мовами, але 3 обов'язковим засвідченням знання обох, живих тією мовою, на викладання якої кожен із них пре- тендував. Екзаменовані мали право подавати на розгляд комісії власні опубліковані праці, докторську роботу чи семінарські виклади, які рецензували визначені директором експерти. Позитивно оцінена робота давала право на проходження наступного етапу - завдань при комісії. Під час ïx виконання екзаменовані з основного предмета, наприклад класичних мов, мали продемонструвати глибокі знання із граматики і стилістики грецької та латинської мов, обізнаність з античною літературою, історією, культурою, політикою, археологією, метрикою; німецької мови - із граматикою, історією літератури й сучасною літературою, науково-критичними працями, політичною історією; до того ж нею як державною мав володіти кожен iз претендентів. Вимоги 3 допоміжного предмета були нижчими [2, с. 56; 16, с. 61-62]: ішлося насамперед про ступінь володіння мовою, якщо це була якась 3 іноземних мов.

У разі отримання незадовільного висновку комісії претендент мав право на повторне (через рік, а за наявності спеціального розпорядження через пів року) складання іспиту. Третя спроба була можлива лише 3 дозволу Міністерства віросповідань і освіти. Після успішного складання всіх трьох етапів іспиту екзаменовані відбували річну практику під керівництвом одного $з$ дійсних учителів гімназії: розширену - у гімназіях, де діяли спеціальні семінари під керівництвом директора, чи звичайну, де умов для таких семінарів не було. Працю на посаді суплента часто зараховували як оцей рік «проб». Упродовж першого півріччя майбутній учитель відвідував лекції свого керівника й інших учителів, давав пробні заняття, а у другому - проводив лекції з екзаменованих предметів. Наприкінці отримував свідоцтво про проходження практики за підписом директора гімназії та вчителя-керівника [16, с. 63].

Висновки і перспективи подальших розробок у цьому напрямі. Викладене дає підстави стверджувати, що в досліджуваний період Міністерство віросповідань та освіти Австро-Угорської імперії, а також Крайова шкільна рада Королівства Галичини й Володимирії як іiі складової частини приділяли увагу середній ланці шкільництва. У суспільстві було розуміння високої місії класичної гімназійної освіти, оскільки лише вона відкривала дорогу до університетських студій, а значить, і до плекання національної еліти. Проблема кадрового потенціалу гімназій належала до переліку найважливіших: від іiі розв'язання залежала ефективність їхньої діяльності. Підготовку вчителів іноземних мов для гімназій Східної Галичини як центральної групи в кожному вчительському колективі здійснювано відповідно до тогочасних вимог і програм. Її започатковувало навчання на філософському факультеті Львівського, Краківського й інших університетів 
держави, а продовженням слугували самоосвіта й саморозвиток кожного упродовж усього професійного шляху, особливо активні в період підготовки і складання кваліфікаційного іспиту. Особливим здобутком аналізованого періоду є усвідомлення ролі педагогічної теорії та практики у професійному становленні вчителя загалом та іноземних мов зокрема. Перспективним уважаємо вивчення особливостей підготовки вчителів іноземних мов для гімназій Східної Галичини в міжвоєнну добу.

\section{ЛІТЕРАТУРА}

1. Вараниця А. Учителі народних шкіл Галичини другої половини XIX - початку XX ст. : дис. ... канд. істор. наук: 07.00.01. Львів, 2018. 315 с.

2. Гаврищак I., Проців О. Галицькі гімназії II половини XIX ст.: кадровий склад і система підготовки педагогічних працівників. Sciences of Europe. 2021. № 66 (3). С. 53-57.

3. Завгородня Т., Прокопів Л., Стражнікова І. Історія педагогіки : навчально-методичний посібник. Івано-Франківськ, 2014. 160 с.

4. Коцюмбас О. Викладацький склад Академічної гімназії у Львові (друга половина XIX - початок XX ст). Наукові записки Тернопільського національного педагогічного університету імені Володимира Гнатюка. Серія «Історія». 2017. Вип. 2 (1). С. 56-61.

5. Курляк І. Українська гімназійна освіта у Галичині (1864-1918 рр.) : монографія. Львів, 1997. 222 с.

6. Лучаковський К. Дамян Ромунальд Гладилович. Посмертна згадка - 3 портретом покійника. Справозданє директора и. к. тімназіг академичнои у Львовњ за роккъ шкоิльный 1892. У Львовъ : Зъ друкарнь товариства имени Шевченка, 1892. С. 43-48.

7. Нагачевська 3. Становлення і розвиток системи професійної підготовки та підвищення кваліфікації учителів у Східній Галичині. Обрії. 2016. № 1 (42). С. 21-26.

8. Справозданє директора ц. к. академичної гімназиї за шкільний рік 1894. У Львові : 3 друкарнї Наукового товариства імени Шевченка, 1894. $24+56$ с.

9. Оконь В. Введение в общую дидактику. Москва, 1990. 382 с.

10. Франко І. Зібрання творів : у 50 т. Київ : Наукова думка, 1978. Т. 18. С. 177-190.

11. Франко І. Допис про дрогобицьку гімназію. Додаткові томи до зібрання творів у $50 \mathrm{~m}$. Київ, 2008. T. 53. C. $10-15$.

12. Buzek J. Rozwój stanu szkól średnich w Galicyi w ciągu ostatnich lat 50 (1859-1909). Muzeum. 1909. Roc. XXV. Dod. 3. S. $176+$ VII.

13. Chodakowska J. Udział Towarzystwa Nauczycieli Szkół Wyższych w walce o polską szkołę średnią w Galicji w latach 1884-1914. Rozprawy z dziejów oświaty. 1984. T. XXVI/84. S. 141-172.

14. Gajak-Toczek M. Franciszek Próchnicki - polonista na wczoraj i dziś. Acta Universitatis Lodziensis. Folia Litteraria Polonica. 2009. Vol. 12. S. 301-325.

15. Galek Cz. Szkoła i nauczyciel w II połowie XIX wieku na północno-wschodnich terenach Monarchii Austro-Węgier w polskiej literaturze pamiętnikarskiej i beletrystycznej. Zamość : Wyższa Szkoła Zarządzania i Administracji w Zamościu, 2012. 295 s.

16. Kramarz H. Nauczyciele gimnazjalni Galicji 1867-1914: Studium historyczno-socjologiczne. Kraków : Wydawnictwo naukowe WSP, 1987.218 s.

17. Leniek J. Kandydaci Stanu akademickiego. Sprawozdanie Dyrekcyi c. k. gimnazyum wyższego w Tarnopolu za rok szkolny 1891. Tarnopol : Z drukarni J. Pawłowskiego. 1891. S. 3-42.

18. Mazur P. Zawód nauczyciela w ciągu dziejów: Skrypt dla studentów z historii wychowania. Chełm : Panstwowa wyszcza szkoła zawodowa, 2015. $135 \mathrm{~s}$.

19. Sprawozdanie dyrekcyi c. k. gimnazyum akademickiego za rok szkolny 1875/6. Lwów : Z drukarni Towarzustwa imienia Szewczenki, 1876.67 + XXV s.

20. Sprawozdanie c. k. Rady szkolnej krajowej o stanie szkół średnich galicyjskich w roku szkolnym 1902/3. We Lwowie : Z drukarni Wł. Łozińskiego, 1903. 91 s.

21. Sprawozdanie c. k. Rady szkolnej krajowej o stanie szkół średnich galicyjskich w roku szkolnym 1905/6. Lwów : Z drukarni Wł. Łozińskiego, 1906. $80 \mathrm{~s}$.

\section{REFERENCES}

1. Varanytsia, A.O. (2018). Uchyteli narodnykh shkil Halychyny druhoi polovyny XIX-pochatku XX stolittia [Teachers of public schools of Galicia in the second half of the XIX-early XX century] (Candidate's dissertation). Lviv [in Ukrainian].

2. Havryshchak, I.I., Protsiv, O.Ia. (2021). Halytski himnazii II polovyny XX st.: kadrovyi sklad i systema pidhotovky pedahohichnykh pratsivnykiv [Galician gymnasiums of the second half of the XIX century: staff and system of training of pedagogical workers]. Sciences of Europe, 66 (3), $53-57$ [in Ukrainian]. 
3. Zavhorodnia, T.K. (2014). Istoriia pedahohiky: navchalno-metodychnyi posibnyk [History of pedagogy: a textbook] / T.K. Zavhorodnia, L.M. Prokopiv, I.V. Strazhnikova. Ivano-Frankivsk [in Ukrainian].

4. Kotsiumbas, O. (2017). Vykladatskyi sklad Akademichnoi himnazii u Lvovi (druha polovyna XIX pochatok XX st.) [Teaching staff of the Academic Gymnasium in Lviv (second half of the XIX - beginning of the XX century)]. Naukovi zapysky Ternopilskoho natsionalnoho pedahohichnoho universytetu imeni Volodymyra Hnatiuka. Seriia: Istoriia - Scientific notes of the Ternopil National Pedagogical University named after Volodymyr Hnatiuk. Series: History (Issue 2 (1)) (pp. 56-62) [in Ukrainian].

5. Kurliak, I.Ye. (1997). Ukrainska himnaziina osvita u Halychyni (1864-1918 rr.): monohrafiia [Ukrainian gymnasium education in Galicia (1864-1918): monograph]. Lviv [in Ukrainian].

6. Luchakovskyi, K. (1892). Damian Romunald Hladylovych. Posmertna zghadka - z portretom pokiinyka [Damian Romuald Gladilovich. Posthumous mention - with a portrait of the deceased]. Spravozdanie dyrektora ts. k. gimnazir akademychnoy u Lvovr za rôkı shkôlnbii 1892 - Director's report to the c. $k$. academic gymnasium in Lviv during the school year 1892 (pp. 43-48). U Lvovъ : Zъ drukarn ymeny Shevchenka [in Ukrainian].

7. Nahachevska, Z. (2016). Stanovlennia i rozvytok systemy profesiinoi pidhotovky ta pidvyshchennia kvalifikatsii uchyteliv u Skhidnii Halychyni [Formation and development of the system of professional training and advanced training of teachers in Eastern Galicia]. Obrii - Horizons. № 1 (42), 21-26 [in Ukrainian].

8. (1894). Spravozdanie dyrektora ts. $k$. akademychnoi gimnazyi za shkilnyi rik 1894 [Report of the director c. to the academic gymnasium for the school year 1894]. U Lvovi : Z drukarni Naukovoho tovarystva imeny Shevchenka [in Ukrainian].

9. Okon, V. (1990). Vvedenie v obschuyu didaktiku [Introduction to general didactics]. Moskva [in Russian].

10. Franko, I. (1978). Zibrannia tvoriv [Collected works] (Vols. 1-50; Vol. 18) (pp. 177-190) Kyiv : Naukova Dumka [in Polish].

11. Franko I. (2008). Dopys pro drohobytsku himnaziiu [An article about the Drohobych gymnasium]. In I. Franko, Dodatkovi tomy do zibrannia tvoriv u 50 t. - Additional volumes to the collection of works in 50 vols.] (Vol. 53) (pp. 10-15) [in Polish].

12. Buzek, J. (1909). Rozwój stanu szkól średnich w Galicyi w ciągu ostatnich lat 50 (1859-1909) [Development of the state of high schools in Galicy in the last 50 years (1859-1909)]. Muzeum - Museum (Ann. XXV. Add. 3) (pp. 176 + VII) [in Polish].

13. Chodakowska, J. (1984). Udział Towarzystwa Nauczycieli Szkół Wyższych w walce o polską szkołę średnią w Galicji w latach 1884-1914 [Participation of the Society of Higher School Teachers in the fight for a Polish secondary school in Galicia in 1884-1914]. Rozprawy z dziejów oświaty - Dissertations on the history of education (Vol. XXVI/84) (pp. 141-172) [in Polish].

14. Gajak-Toczek, M. (2009). Franciszek Próchnicki - polonista na wczoraj i dziś [Franciszek Próchnicki Polish teacher for yesterday and today]. Acta Universitatis Lodziensis. Folia Litteraria Polonica - Acta Universitatis Lodziensis. Litteraria Polonica foil (Vol. 12) (pp. 301-325) [in Polish].

15. Galek, Cz. (2012). Szkoła i nauczyciel w II połowie XIX wieku na pótnocno-wschodnich terenach Monarchii Austro-Węgier w polskiej literaturze pamiętnikarskiej i beletrystycznej [School and teacher in the second half of the nineteenth century in the north-eastern territories of the Austro-Hungarian Monarchy in Polish diary and fiction literature]. Zamość : Wyższa Szkoła Zarządzania i Administracji w Zamościu [in Polish].

16. Kramarz, H. (1987). Nauczyciele gimnazjalni Galicji 1867-1914: Studium historyczno-socjologiczne [Gymnasium teachers in Galicia 1867-1914: Historical and sociological study]. Kraków : Wydawnictwo naukowe WSP [in Polish].

17. Leniek, J. (1891). Kandydaci Stanu akademickiego [Candidates of the academic status]. Sprawozdanie Dyrekcyi c. $k$. gimnazyum wyższego w Tarnopolu za rok szkolny 1891 - Report of the Directorate of c. $k$. higher secondary school in Ternopil for the school year 1891 (pp. 3-42). Tarnopol : Z drukarni J. Pawłowskiego [in Polish].

18. Mazur, P. (2015). Zawód nauczyciela w ciagu dziejów: Skrypt dla studentów z historii wychowania [The teaching profession throughout history. Script for students of the history of education]. Chełm : Panstwowa wyszcza szkoła zawodowa [in Polish].

19. (1876). Sprawozdanie dyrekcyi c. k. gimnazyum akademickiego za rok szkolny 1875/6. Lwów [Report of the director of the c. K. Academic junior high school for the school year 1875/6]. Lviv : Z drukarni Towarzustwa imienia Szewczenki [in Polish].

20. (1903). Sprawozdanie c. k. Rady szkolnej krajowej o stanie szkót średnich galicyjskich w roku szkolnym 1902/3 [Report of the c. $k$. Of the National School Council on the condition of Galician secondary schools in the 1902/3 school year]. We Lwowie : Z drukarni Wł. Łozińskiego [in Polish].

21. (1906). Sprawozdanie c. k. Rady szkolnej krajowej o stanie szkót średnich galicyjskich w roku szkolnym $1905 / 6$ [Report of the c. $k$. Of the National School Council on the condition of Galician secondary schools in the 1905/6 school year]. Lwów : Z drukarni Wł. Łozińskiego [in Polish]. 